\title{
Forestry in Kenya
}

$\mathrm{T}$ HE annual forest report for 1934 for the Colony and Protectorate of Kenya (Nairobi : Govern. ment Printer, 1935) is of interest on the subject of reservation of forests. The total reserved forest area in 1921 was 3,207 square miles ; in 1934 it amounted to 4,711 square miles. During this period, some areas of reserve forest have been given up.

From the report, the reasons for giving up areas of forest already reserved is not clear. The common reason for such returns to the Civil Department is that the land is required, and can be more profitably used for, agriculture. This is not given as the reason in Kenya. The Conservator writes: "In making these excisions from the forest very careful consideration is given to each case, and no land that is thought to be of value to the forest, climatically or commercially, is given up". It is somewhat difficult to visualize the uses to which land of no value to the Forest Department can be put. In spite of this statement and the admission that there is a certain amount of anxiety in the Colony as to the adequacy of the forest area, "and a feeling that this area is being seriously diminished by constant excisions", the report states that, during the year, the Kenya Land Commission recommended that approximately 13,500 acres should be excised from forest reserves in settlement of various claims. The Department considers that "little real damage was done" ; but the Commission itself records in its report that "We agree with the conclusion that the items shown in the schedule [that is, the land that was surrendered] should be regarded as the limit of sacrifice which the forest should be required to suffer".

This appears to be strange reading. In the administration of a country, nowadays, a clear understanding of the position played by the forests, both economic and climatic, should be possible and form part of the policy of governance. Either the forest is required to fulfil these vital interests of the population or it is not. Once the maintenance of the water supplies of a country, provision for local requirements of the population, and such commercial interests as may be considered advisable to provide for have been arranged, the rest of the forests may be sacrificed, in other words, felled and suffered to disappear with equanimity in the interests of other and more serviceable utilization of the land. But such disposal of the land does not and should not entail "the limit of sacrifice which the forest should be required to suffer". It would appear in Kenya that, for some reasons not apparent in the report, land previously forming forest reserves is being alienated at some danger to the maintenance of a correct proportion of forest, even though there appears to be some 800 1,000 square miles still to reserve, lying mainly within the native reserves of Meru, Masai, Cherangani and Marakwet.

The cuts in expenditure account for much during the last few years; but in view of the fact that there has been an expert forest service in Kenya for some considerable period, it is depressing to read that "it was still impossible to detail an officer or officers for the special work of enumerations and compilation of working plans; divisional staffs cannot be expected to make much progress in such important work".

The chief work in connexion with regenerating the forests is by exploiting the forest produce indigenous to the areas it is desired to plant, and then, by means of controlled shifting cultivation or toungya, replanting suitable trees in regular plantations. In such work, as the report states, definite plans are required. But plantations will not replace square miles of indigenous forest, even if they are putting back a greater potential tonnage than that of the present annual cut. To know what is standing in the forests should be the vital factor antecedent to exploitation. Until this factor has been ascertained, it appears irrelevant to consider markets available for export.

\section{Rural Custom in Civilized Communities}

$I^{\mathrm{T}}$ is an interesting coincidence that the claims of ancient custom and conservatism in civilized communities as worthy of observation and record should be urged almost simultaneously from three different sources, of which one is far removed from the other two-England, France and South Africa.

Mr. R. U. Sayce in Man of April, emphasizing the importance for anthropology of the study of civilized, as well as uncivilized, peoples, refers as a case in point to the remarkable variety shown in British agricultural implements in response to local conditions and requirements. Not all, indeed, are of British origin. Some have been introduced by foreign workmen, as, for example, the implements used in cutting peat near Manchester and the implements of the sugar-beet industry, both of which are of Dutch origin. The bill-hook affords an interesting example of this variation. Mr. Sayce figures no less than forty-eight distinct varieties of the bill-hook, all of which are now manufactured, and are in use, in different parts of England and Wales. That Mr. Sayce is not entirely ploughing a lonely furrow is indicated by the fact that in the same month of April a collection of implements illustrating the changes in agriculture during the last hundred years was presented to the Colchester and Essex Museum.

Apart from its cultural value, the study of traditional types of agricultural implements may have a distinctly practical bearing on the work of the archæologist in affording a clue to the character and purpose of a find of unusual or previously unknown type. This latter function of the study is stressed by M. L. Franchet in an introductory sketch of agricultural ethnography (Revue des Sciences, 111, April 
$11,1936)$, in which he dwells on continuity in type as a regional characteristic. Analogies to archæological finds, he points out, have been sought among primitive peoples, geographically remote, and often have led to erroneous results; whereas investigation in the area in which they were found, among the people of to-day, would have revealed in many instances the identical type, or a derivative, in everyday use. M. Franchet himself has interpreted his archæological finds by this method with illuminating effect, and he has also traced modern implements back to their origin in the bronze age. His researches in the forest of Montmorency find an ancestry for certain implements which leads back to the stone age, while the equipment of viticulture and wine-making goes back, with the industry, to Gallic times, though, of course, not all the implements in use are of an equally remote origin. There is a pregnant reminder that the conversion of the sword into a ploughshare is more than a rhetorical trope in the observation that in primitive conditions the weapons of war do become the imple. ments of peaceful occupations when hostilities cease.

A legitimate pride of descent and a half-humorous, but wholly determined, practice of traditional ways of doing certain things is attributed to the Cape population of Dutch descent in a record of surviving customs by Eric Rosenthal ("Old Time Survivals in South Africa". Government Printer, Pretoria, 1936. Pp. 38). The survival of so much that, on a superficial view, is obsolete may seem remarkable in a community that is now essentially up to date, and of which some of the industries are highly mechanized. To some extent this may be due to a racial pride and race consciousness; but the real explanation lies deeper. It is part of an enduring environmental adaptation. The clue is afforded by the survival of the old ox-wagon, virtually unchanged since its first introduction from Holland by Jan van Riebeck in 1632, except for the addition of a brake in the eighteen-sixties, yet of which there are more than a hundred thousand in use in South Africa side by side with the automobile. This apparent anomaly may be explained by the fact that the ox wagon has been the efficient cause in the development of the characteristic South African civilization. When built in the traditional way and from the traditional materials, it is still the best, and indeed the only, means of transport which is fully adapted to the geographical conditions and the social and economic needs of the country. One useful feature of ox-wagon travel, the 'outspan' for night camping, still found in every community, serves both the old and the modern need in a country where distances are great and hotel facilities few.

\section{Empire Surveys}

$\mathrm{F}^{\mathrm{a}}$ RMERLY it was difficult for surveyors, more or less isolated in the Dominions and Colonies, to keep in touch with the advances in technique which are constantly occurring both as regards instruments and methods, cut off as they are from their fellow surveyors.

The institution of periodical conferences, held in the heart of the Empire, under the auspices of the Colonial and War Offices, has changed all this. Surveyors from different parts of the Empire meet and get in touch with each other as they never did before. Nothing but good can result from this. There has also been established a quarterly journal, the Empire Survey Review, devoted to survey technique and the discussion of matters of interest to the surveyor. At last year's conference, all the Dominions (except New Zealand), India and Colonies possessing survey departments, were represented, as well as many British scientific societies and universities.

At the conference, the report of which has lately been published*, some forty papers bearing on all branches of surveying and dealing with the latest instrumental developments were read and discussed. Of these, no less than eight dealt with matters con. nected with air survey, showing the importance now attached to this branch of the subject.

From such a mass of matter it is not easy to single out for notice particular subjects. Major M. Hotine has an interesting paper on signals for triangulation. Sufficient attention is not always paid to signals where accurate work has to be done. As the author points out in the case of opaque signals made of wood, it is very necessary in order to avoid warping

* Conference of Empire Survey Officers 1935. Report of Proceedings. (Colonial No. 111.) Pp. vi $+377+36$ plates. (London: H.M. Stationery Office, 1936.) 20s. net. and the movement of the signal due to the drying of material after erection, that they should be made of seasoned timber, instead of, as is usually done, from wood eut on the spot. Incidentally, Major Hotine points out that if primary triangulation is undertaken at all, it should be of first-class order and not "only good enough for immediate purposes". Someone is sure to want to extend it in the future, in which case it may have to be done all over again. Therefore every precaution should be taken with the observations, the best instruments should be used and suitable signals well centred over the marks, or the work will not conform with first-class triangulation. A new type of electric night projector is being brought out by Messrs. Cooke, Troughton and Simms, Ltd., which can be worked by a 12-volt accumulator such as is carried on a motor car. We understand it is being used by the Ordnance Survey in the retriangulation of Great Britain now in progress.

Many papers are read chiefly with the view of encouraging discussion. For example, a new instrument is experimented with; it is of considerable advantage to know what the experience of others has been with an instrument of the kind. When we consider how grudgingly money is allotted for survey purposes in Great Britain, it is astonishing to read that more than $£ 6$ per acre is spent on the survey of Georgetown and Malacca in the Federated Malay States. The value of survey out there is evidently known and appreciated.

Perhaps one of the most remarkable papers read before the conference was by Lieut. E. H. Thompson, R.E., on "An Automatic Plotting Machine for Air Photographs". This machine is from the designs of Mr. Fourcade, who has been working at this difficult problem for some years. Lieut. Thompson has 